\title{
Knowledge, Attitude and Practice of Clients towards COVID-19 at Primary Healthcare Facilities in Rivers State, Nigeria
}

\section{Clement Kevin Edet}

Rivers State Primary Health Care Management Board

Anthony lke Wegbom ( $\square$ wegbomanthony@gmail.com )

Captain Elechi Amadi Polytechnic https://orcid.org/0000-0001-5589-7714

Victor Alangibi Kiri

Northumbria University Newcastle

\section{Research}

Keywords: COVID-19, KAP, Clients, Primary Healthcare Facility, Rivers State, Nigeria

Posted Date: July 13th, 2020

DOI: https://doi.org/10.21203/rs.3.rs-40966/v1

License: (1) This work is licensed under a Creative Commons Attribution 4.0 International License.

Read Full License

Version of Record: A version of this preprint was published at International Journal of TROPICAL DISEASE \& Health on October 19th, 2020. See the published version at https://doi.org/10.9734/ijtdh/2020/v41i1530360. 


\section{Abstract}

Introduction: The outbreak of coronavirus (COVID-19) has impacted the lifestyles of people all over the globe as well as the economies of virtually every country. Several control measures have been introduced by both the State and Federal governments to fight the disease since its outbreak in Nigeria. In spite of all the measures, the disease is still ravaging the country. Therefore, this study investigated the knowledge, attitudes, and practices (KAP) of the clients who attended public primary healthcare facilities (PHFs) in Rivers State, Nigeria about COVID-19.

Methods: A cross-sectional study was conducted involving the clients seeking care at the 92 PHFs across the 23 Local Government Areas (LGAs) of Rivers State, Nigeria. The respondents were selected using simple random sampling and data were analysed using mean and standard deviation, percentages, chisquare test and binary logistic regression.

Results: A total of 434 respondents voluntarily participated in the study out of 460 questionnaires that were distributed, indicating a high response rate of $94.3 \%$. The proportions of respondents with scores moderate and above in KAP were 86.6\% (62.9+23.7), 80.6\% (57.6+23.0), and 58.0\% (30.8+27.2) respectively. Occupation, educational level, and senatorial district of respondents were significantly associated with knowledge and attitude $(P<0.05)$. Preventive practice against COVID-19 was influenced by age and senatorial district among patients attending primary health facilities $(P<0.05)$. Also, the knowledge level was significantly associated with both attitude and COVID-19 related practices $(P=0.000)$. The multiple logistic regression results revealed some demographics with significant association with KAP. Respondents who have sufficient knowledge about COVID-19 were significantly less likely to have a negative attitude and to adopt poor COVID-19 related practices than those that had insufficient knowledge.

Conclusion: Based on the findings of this study, we suggest public health education programs on COVID19 should principally be targeted at individuals with low knowledge level, lower educational attainment, and those residing in the Rivers South-East senatorial zone. Such efforts may mitigate the impact of COVID-19 on the target population in Rivers State.

\section{Introduction}

The outbreak of coronavirus (COVID-19) has impacted the lifestyles of people all over the globe as well as the economies of virtually every country. Infection of humans by the virus was first reported in December 2019 in Wuhan, China [1], and has speedily affected more than 215 countries [2]. The World Health Organization (WHO) has since March 12, 2020, declared the disease a pandemic [3]. As of 6th July 2020 , there were $11,418,475$ COVID-19 cases and 533,958 deaths globally [4].

Between 27th February 2020 when the first case of the virus was reported in Lagos State, Nigeria and 6th July 2020, the number of confirmed cases in that West African country, has increased rapidly to 28,711 including 645 deaths [5, 6]- making Nigeria the third highest in Africa, next to South Africa and Egypt [4]. 
Rivers State, one of the oil-producing States in Nigeria is considered the epicenter of the disease in the South-South geopolitical zone and the fifth most affected State in the country with over 1,183 confirmed cases and 41 deaths. Over the period, Lagos State, the Federal Capital Territory (FCT) Abuja, Kano, and Oyo States being those with higher burden [6].

Several control measures have been introduced by both the State and Federal governments to fight the disease since its outbreak- the former through their ministries of Health and the later, through the Nigeria Center for Disease Control (NCDC) under the leadership of the Presidential Task Force (PTF) on COVID19. These include the closing of land and sea borders, airports, and all public spaces, such as open markets and schools. In spite of all these measures, the disease is still ravaging the country. Thus, there is need for public commitment and responsibility in the fight against the disease by their adhering to all the control measures and guidelines, which according to the KAP theory are principally affected by knowledge, attitudes, and COVID-19 related practices (KAP) of the population $[7,8]$.

To facilitate the fight against COVID-19 in Nigeria, it is imperative to assess and understand the awareness of COVID-19 by the public. Therefore, this study investigated the KAP of the clients who attended public primary healthcare facilities (PHFs) in Rivers State, Nigeria about COVID-19.

\section{Methods}

\section{Study design and population of the study}

A cross-sectional survey was conducted involving the clients seeking care at the public primary healthcare facilities in the 23 local government areas (LGAs) of Rivers State, Nigeria as respondents.

\section{Sample size and sampling techniques}

We estimated a sample size of 378 to command $90 \%$ power at $5 \%$ significance level, using an online sample size calculator, but chose a study sample of 460 to allow for possible cases of non-response or invalid response. Hence, 20 questionnaires were distributed to each of the 23 LGAs. Four health facilities were selected by simple random sampling from a list of facilities in each LGA, making it a total of 92 PHFs. Similarly, we randomly selected five respondents from each of the 4 facilities, among the clients who attended the facilities on the exact day of survey.

\section{Data collection}

Data for the study was collected from the PHFs across the 23 LGAs of Rivers State from $16^{\text {th }}$ to $20^{\text {th }}$ June 2020 using an adapted WHO questionnaire on detection, prevention, response, and control of COVID-19 [9]. The questionnaire was divided into two parts: demographics and KAP. The demographic characteristics were gender, age, marital status, occupation, educational level, and Local government area. The KAP part had 26 questions relating to knowledge, 15 relating to attitude, and 12 questions on the actual COVID-19 related practices of the respondents about COVID-19. A correct answer was assigned 
1 point while an "incorrect/I don't know" was assigned 0 point. A higher score denoted a good knowledge, whereas a lower score denoted a poor knowledge of COVID-19; the same also applied to attitude and COVID-19 related practices.

\section{Statistical analysis}

Data were entered into the Statistical Package for Social Science (SPSS) version 25, while all analysis were done using both SPSS and the STATA version 15 (Stata Corp., College Station, TX, USA) software. Using descriptive analysis, the results for each of the quantitative variables were presented as mean \pm standard deviation, whilst those for the categorical variables were reported as frequency and percentage. The association between the responses on KAP and demographic characteristics were tested using the Chi-square test. Binary logistic regression was performed to identify factors associated with KAP and statistical significance was assessed at $\mathrm{P}<0.05$.

\section{Results}

A total of 434 respondents voluntarily participated in the study out of 460 questionnaires that were distributed. This showed a high response rate of $94.3 \%$. Table 1 reveals the statistics on overall knowledge, attitude, and COVID-19 related practices in mean \pm standard deviation and percentages in three categories (low, moderate, and high). The proportions of respondents that have moderate and above scores in knowledge, attitude and COVID-19 related practices are 86.6\% $(62.9+23.7), 80.6 \%(57.6$ $+23.0)$, and $58.0 \%(30.8+27.2)$ respectively. Table 2 shows that majority of the respondents are female (67.3\%), aged 25 to 35 (47.7\%), non-healthcare workers (67.2\%), attained tertiary education (53.8\%), and married $(66.6 \%)$. The mean age (with standard deviation) of the respondents is $33.17 \pm 9.07$.

Table 3 displays the clients' mean score for knowledge, attitude, and COVID-19 related practices towards COVID-19 across different groups of demographic characteristics. It shows that age was significantly associated with COVID-19 related practices $(P=0.008)$, but not with knowledge and attitude. Occupation, educational level, and senatorial district of respondents were also significantly associated with knowledge and attitude $(\mathrm{P}<0.05)$. Also, the knowledge level was significantly associated with both attitude and COVID-19 related practices $(P=0.000)$. Whereas gender and marital status were not significantly related to neither knowledge, attitude nor COVID-19 related practices; preventive practice against COVID-19 was also influenced by age and senatorial district among patients attending primary health facilities $(P<0.05)$. It is worthy of note that two previous studies in Nigeria [10] and China [11] had also identified educational level as a risk factor for COVID-19 related practices.

Table 4 shows the results from the multiple logistic regression involving some demographics that have significant association with KAP as shown in Table 3. The table reveals that respondents who attained tertiary education were significantly less likely to have low knowledge of COVID-19 $(O R=0.15,95 \% \mathrm{Cl}=$ 0.04-0.55) compared to those that have no formal education and a similar association was found with attitude to COVID-19: compared with those with no formal education, people with high educational attainment were significantly less likely to have negative attitude to COVID-19- $(\mathrm{OR}=0.77,95 \% \mathrm{Cl}=0.79$ - 
0.88 for secondary and $\mathrm{OR}=0.60,95 \% \mathrm{Cl}=0.47-0.79$ for tertiary). Those that reside in the Rivers SouthEast senatorial zone significantly exhibited a more negative attitude toward COVID-19 (OR $=3.21,95 \% \mathrm{Cl}$ $=1.63-6.35)$ compared to those that reside in the East. Those who have sufficient knowledge about COVID-19 were significantly less likely to have a negative attitude than those that have insufficient knowledge- moderate $(\mathrm{OR}=0.15,95 \% \mathrm{Cl}=0.08-0.29)$ and high $(\mathrm{OR}=0.11,95 \% \mathrm{Cl}=0.04-0.25)$.

Furthermore, with regard to COVID-19 related practices, respondents that attained a tertiary level of education are less likely to have poor COVID-19 related practices and adherence to outlined guidelines $(\mathrm{OR}=0.64,95 \% \mathrm{Cl}=0.48-0.83)$ compared to those that have no formal education. Like attitude, residing in the Rivers South-East senatorial zone was significantly associated with poor COVID-19 related practices $(\mathrm{OR}=2.64,95 \% \mathrm{Cl}=1.46-4.79)$ than residing in the East. Moderate knowledge and high knowledge were significantly less likely to adopt poor COVID-19 related practices $(O R=0.24,95 \% \mathrm{Cl}=$ $0.12-0.47)$ and $(\mathrm{OR}=0.09,95 \% \mathrm{Cl}=0.04-0.24)$ respectively than those that have low knowledge towards COVID-19.

Table 1

Number of questions, scores and level of KAP regarding COVID-19

\begin{tabular}{|lllllll|}
\hline Levels & $\begin{array}{l}\text { Number of } \\
\text { Questions }\end{array}$ & $\begin{array}{l}\text { Range of } \\
\text { scores }\end{array}$ & $\begin{array}{l}\text { Total score (Mean } \pm \\
\text { SD) }\end{array}$ & Level (\%) & \\
\hline & & & & Low & Moderate & High \\
\hline Knowledge & 26 & $0-26$ & $19.46 \pm 4.17$ & 13.4 & 62.9 & 23.7 \\
\hline Attitude & 15 & $0-15$ & $10.44 \pm 2.81$ & 19.4 & 57.6 & 23.0 \\
\hline Practice & 12 & $0-12$ & $6.24 \pm 2.68$ & 42.0 & 30.8 & 27.2 \\
\hline
\end{tabular}


Table 2

Distribution of Clients According to their Demographic Characteristics

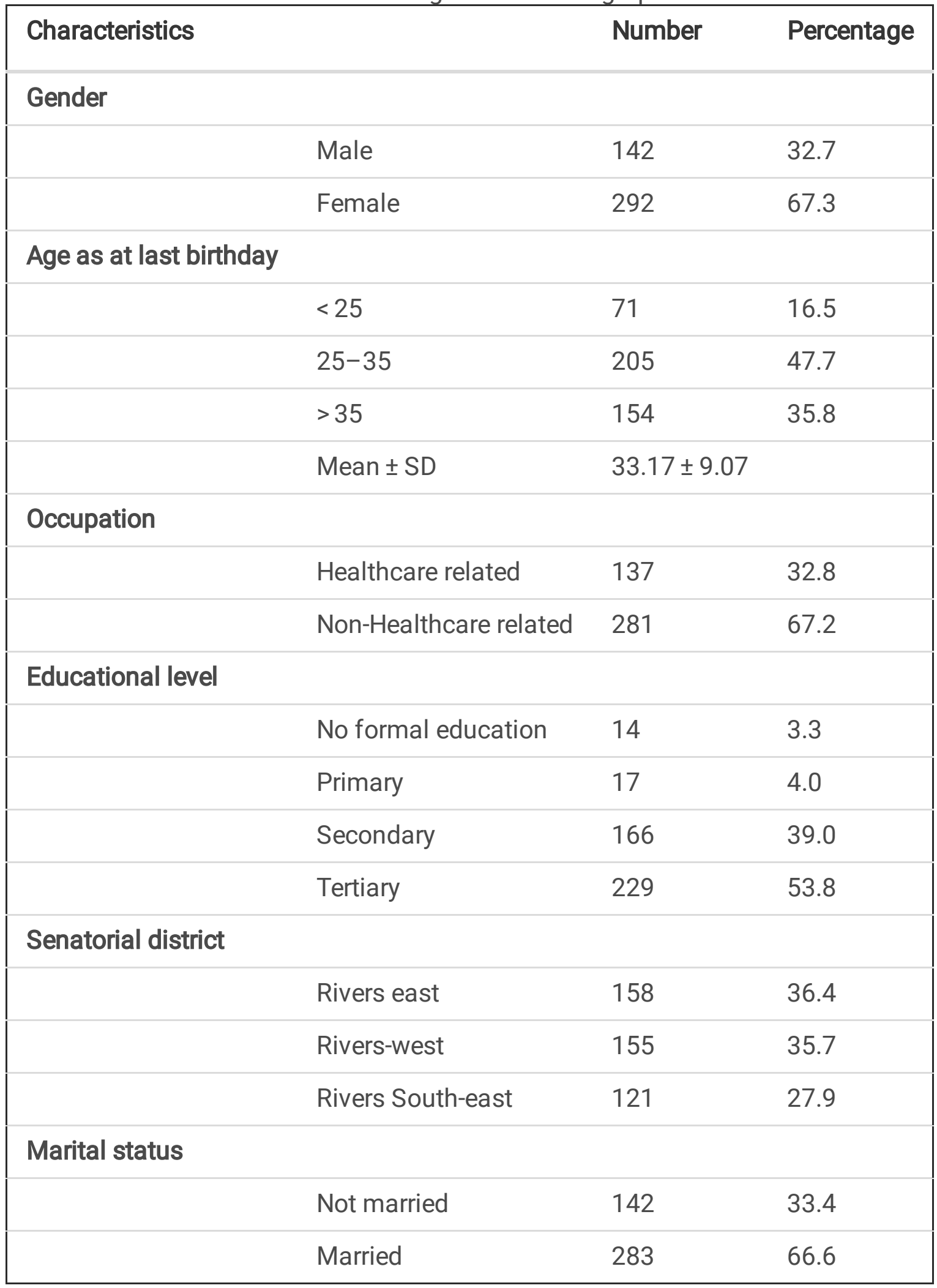


Table 3

Mean score of clients on the level of KAP

Characteristics

\begin{tabular}{|c|c|c|c|c|c|c|}
\hline & Knowledge & P-value & Attitude & P-value & Practice & P-value \\
\hline Gender & & 0.187 & & 0.809 & & 0.231 \\
\hline Male & $19.94 \pm 3.54$ & & $10.39 \pm 2.76$ & & $7.83 \pm 3.06$ & \\
\hline Female & $19.22 \pm 4.17$ & & $10.46 \pm 2.84$ & & $8.44 \pm 2.45$ & \\
\hline Age as at last birthday & & 0.643 & & 0.333 & & 0.008 \\
\hline$<25$ & $18.97 \pm 5.00$ & & $10.54 \pm 3.30$ & & $7.99 \pm 3.55$ & \\
\hline $25-35$ & $19.69 \pm 3.70$ & & $10.46 \pm 2.62$ & & $8.44 \pm 2.45$ & \\
\hline$>35$ & $19.37 \pm 4.35$ & & $10.39 \pm 2.79$ & & $8.10 \pm 2.51$ & \\
\hline Occupation & & 0.019 & & 0.047 & & 0.124 \\
\hline Healthcare related & $20.28 \pm 3.55$ & & $10.83 \pm 2.43$ & & $8.69 \pm 2.34$ & \\
\hline Non-Healthcare related & $19.04 \pm 4.40$ & & $10.46 \pm 2.80$ & & $7.99 \pm 2.85$ & \\
\hline Educational level & & 0.000 & & 0.036 & & 0.191 \\
\hline No formal education & $16.07 \pm 7.66$ & & $9.00 \pm 3.68$ & & $8.64 \pm 3.00$ & \\
\hline Primary & $18.12 \pm 5.42$ & & $10.24 \pm 2.66$ & & $8.35 \pm 1.80$ & \\
\hline Secondary & $18.67 \pm 4.54$ & & $10.02 \pm 3.08$ & & $7.80 \pm 3.01$ & \\
\hline Tertiary & $20.43 \pm 4.19$ & & $10.86 \pm 2.44$ & & $8.57 \pm 2.39$ & \\
\hline Senatorial district & & 0.000 & & 0.000 & & 0.000 \\
\hline Rivers-east & $19.87 \pm 4.04$ & & $11.07 \pm 2.69$ & & $8.59 \pm 2.21$ & \\
\hline Rivers-west & $19.50 \pm 4.14$ & & $10.54 \pm 2.67$ & & $8.76 \pm 2.45$ & \\
\hline Rivers South-east & $18.78 \pm 4.31$ & & $9.45 \pm 2.88$ & & $7.15 \pm 3.21$ & \\
\hline Marital status & & 0.520 & & 0.502 & & 0.197 \\
\hline Not married & $19.76 \pm 3.37$ & & $10.66 \pm 2.58$ & & $8.16 \pm 2.85$ & \\
\hline Married & $19.40 \pm 4.31$ & & $10.37 \pm 2.85$ & & $8.32 \pm 2.58$ & \\
\hline Knowledge & NA & NA & & 0.000 & & 0.000 \\
\hline Low & & & $7.26 \pm 3.68$ & & $5.84 \pm 3.44$ & \\
\hline Moderate & & & $10.72 \pm 2.29$ & & $8.43 \pm 2.46$ & \\
\hline
\end{tabular}

Mean \pm Standard Deviation

Knowledge P-value

0.187

$10.39 \pm 2.76$

$19.22 \pm 4.17$

$10.46 \pm 2.84$

0.333

Age as at last birthday 
Characteristics

High

Significant at $\mathrm{P}<0.05$
Mean \pm Standard Deviation

$11.47 \pm 2.20$

$9.08 \pm 1.91$

Table 4

Logistic Regression for Knowledge, Attribute and Practice of Clients towards COVID-19 in Rivers State

\begin{tabular}{|c|c|c|c|c|c|c|}
\hline \multirow[b]{2}{*}{ Characteristics } & \multicolumn{2}{|c|}{ Knowledge } & \multicolumn{2}{|c|}{ Attitude } & \multicolumn{2}{|c|}{ Practice } \\
\hline & OR & $95 \% \mathrm{Cl}$ for OR & OR & $95 \% \mathrm{Cl}$ for OR & OR & $95 \% \mathrm{Cl}$ for OR \\
\hline Age as at last birthday & NA & NA & NA & NA & & \\
\hline$<25$ & & & & & 1.00 & \\
\hline $25-35$ & & & & & 1.02 & $0.51-2.06$ \\
\hline$>35$ & & & & & 1.44 & $0.70-2.98$ \\
\hline Occupation & & & & & NA & NA \\
\hline Healthcare related & 1.00 & & 1.00 & & & \\
\hline Non-Healthcare related & 1.59 & $0.70-3.57$ & 1.48 & $0.79-2.78$ & & \\
\hline \multicolumn{7}{|l|}{ Educational level } \\
\hline No formal education & 1.00 & & 1.00 & & 1.00 & \\
\hline Primary & 0.83 & $0.16-4.28$ & 0.93 & $0.85-1.03$ & 0.96 & $0.79-1.07$ \\
\hline Secondary & 0.45 & $0.13-1.63$ & $0.77 \star$ & $0.79-0.88$ & 0.89 & $0.79-1.09$ \\
\hline Tertiary & $0.15^{\star}$ & $0.04-0.55$ & $0.60 *$ & $0.47-0.79$ & $0.64^{*}$ & $0.48-0.83$ \\
\hline \multicolumn{7}{|l|}{ Senatorial district } \\
\hline Rivers-east & 1.00 & & 1.00 & & 1.00 & \\
\hline Rivers-west & 0.73 & $0.34-1.57$ & 1.64 & $0.80-3.36$ & 0.85 & $0.45-1.58$ \\
\hline Rivers South-east & 1.40 & $0.70-2.81$ & $3.21^{\star}$ & $1.63-6.35$ & $2.64^{\star}$ & $1.46-4.79$ \\
\hline Knowledge & NA & NA & & & & \\
\hline Low & & & 1.00 & & 1.00 & \\
\hline Moderate & & & $0.15^{\star}$ & $0.08-0.29$ & $0.24^{*}$ & $0.12-0.47$ \\
\hline High & & & $0.11 *$ & $0.04-0.25$ & $0.09 *$ & $0.04-0.24$ \\
\hline
\end{tabular}




\section{Discussion}

To the best of our knowledge, this is the first study to investigate the KAP of patients towards COVID-19 who sought care at PHFs in Nigeria, although there are studies on KAP of healthcare workers and the general population towards this disease both in Nigeria and abroad [11-14]. Like previous studies in China [13] and Iran [15], the study was dominated by the female and those who had attend tertiary education. The study found that most of the respondents were knowledgeable and had a positive attitude towards COVID-19. This is consistent with other studies in China [13] and Iran [14] but contradicts another study in Bangladeshi [15]. The possible explanation for the association between sufficient knowledge and positive attitude might be because the study population was dominated by the well-educated. However, sufficient knowledge and positive attitude among respondents did not translate to adoption of good preventive COVID-19 related practices. The finding contradicted studies on KAP of healthcare workers in Ugandan [16] and Saudi Arabia [17]. The poor preventive practices among the clients might be attributed to the low fatality and high recovery rates of the disease in the country [6].

The study also identified some demographic factors which are associated with insufficient knowledge, negative attitude, and poor COVID-19 related practices among patients that seek care at the public primary healthcare facilities in Rivers State. Occupation, educational level, and senatorial zone were significantly associated with knowledge level, so also were occupation, educational level, senatorial zone and knowledge level significantly associated with attitude; COVID-19 related practices were significantly associated with age, senatorial zone and knowledge level. The findings of this study regarding demographic variables associated with KAP towards COVID-19 are partially comparable to those found in previous studies $[14,15,18,19]$. Also, our study revealed a significant association between knowledge level with attitude and COVID-19 related practices- similarly reported by an earlier study in Iran [15].

Furthermore, regarding the level of educational attainment, the findings of this study are comparable with other studies in Nigeria and abroad $[10,14,15]$ which revealed that those that attained higher education are significantly less likely to have low knowledge, negative attitude, and poor preventive practice towards COVID-19. Our study also revealed that those residing in the Rivers South-East sensational zone significantly had a more negative attitude and poor preventive practices toward COVID-19 compared to those that residing in the Rivers-East and Rivers-West senatorial zones. One notable possible explanation for this is insufficient public health education awareness. The risks of negative attitude and poor COVID19 related practices were significantly less among patients who had a moderate and high level of knowledge about COVID-19 as was reported by a previous study in Iran [15].

\section{Conclusion}

Our findings revealed that patients at public primary healthcare facilities in Rivers State, demonstrated good knowledge, positive attitudes, but unreasonable preventive practice about COVID-19. We found evidence of a number of associations between the knowledge levels of the patients and their attitude and preventive practice. On the basis of these findings, we suggest public health education programs on 
COVID-19 should principally be targeted at individuals with low knowledge level, lower educational attainment, and that more efforts are needed for residents of the Rivers South-East senatorial zone. We think such efforts may enhance the right attitude and the adoption of unharmful COVID-19 related practices which are necessary mitigating the impact of COVID-19 on the target population in Rivers State.

\section{Abbreviations}

$\mathrm{Cl}$ Confidence interval

KAP Knowledge attitude and practice

LGA Local government area

NA Not applicable

OR Odd ratio

PHFs Primary healthcare facilities

\section{Declarations}

\section{Ethical Issues}

The study was approved by the Rivers State Health Research Ethics Committee (RSHMB/RSHREC/11.20/VOL.8/063). The questionnaire was administered with strict adherence to the standard instructions on physical distancing, wearing of face masks and hand cloves, and with the written consent of the respondents.

\section{Availability of data}

The dataset used for this study is available upon a reasonable request from the corresponding author.

\section{Competing of Interest}

None to declare.

\section{Funding}

None for this study

\section{Authors' contributions}

Concepts, Study design, Literature Search and Writing First Draft: CKE and AIW. Data Entering, Cleaning and Statistical Analysis: AIW. Writing Review and Editing: CKE and VAK. Supervision: VAK. All authors 
read and approved the final manuscript.

\section{Acknowledgments}

We thank all patients that voluntarily participated in the survey and the PHCWs for their contributions towards the survey.

\section{Consent for publication}

Not applicable

\section{Availability of data}

\section{References}

1. World Health Organization (WHO). Coronavirus disease 2019 (COVID-19) Situation Report94.Avaiable from: https://www.who.int/docs/default source/coronaviruse/situation reports/20200423-sitrep-94-covid-19.pdf?sfvrsn = b8304bf0_4.

2. World Health Organization (WHO). Coronavirus disease (COVID-19) Pandemic outbreak situation. Available from: https://www.who.int/emergencies/diseases/novel-coronavirus-2019?g/outbreaksituation/report.

3. World Health Organization. WHO announces COVID-19 outbreak a Pandemic. Available from: http://www.euro.who.int/en/health-topics/health-emergencies/coronaviruscovid19/news/news/2020/3/who-announces-covid-19-outbreak-a-pandemic.

4. European Centre for Disease Prevention and Control on July 6th. 2020. Available from: https://www.ecdc.europa.eu/en/geographical-distribution-2019-ncov-cases.

5. Nigeria Centre for Disease Control and Prevention. Avaiable from: https://ncdc.gov.ng/news/227/first-case-of-corona-virus-disease-confirmed-in-nigeria.

6. Nigeria Centre for Disease Control and Prevention on July 6th. 2020. Available from: https://covid19.ncdc.gov.ng/.

7. Ajilore K, Atakiti I, Onyenankeya K. College students' knowledge, attitudes and adherence to public service announcements on Ebola in Nigeria: Suggestions for improving future Ebola prevention education programmes. Health Edu J. 2017;76(6):648-60. 10.

8. Tachfouti N, Slama K, Berraho M, Nejjari C. The impact of knowledge and attitudes on adherence to tuberculosis treatment: a case-control study in a Moroccan region. The Pan Afr Med J. 2012;12:52. Epub 2012/09/01.

9. World Health Organization. Emerging respiratory viruses, including COVID-19: methods for detection, prevention, response, and control. Avaiable from: https://openwho.org/courses/introductionto-ncov.

10. $10.1101 / 2020.06 .11 .20127936$ 
Bindawa M, Abdulsalam M, Bello A, Ibrahim MI, Usman A, Nasir A, et al. Corona Virus Disease 2019 (COVID-19): Knowledge, attitudes, practices (KAP) and misconceptions in the general population of Katsina State, Nigeria. 2020; Available from: doi: https://doi.org/10.1101/2020.06.11.20127936.

11. Zhou M, Tang F, Wang Y, Nie H, Zhang L, You G, Zhang M. Knowledge, attitude and practice regarding COVID-19 among health care workers in Henan, China. J Hosp Infect. 2020. https://doi.org/10.1016/j.jhin.2020.04.012.

12. Ogolodom MP, Mbaba AN, Alazigha N, Erondu OF, Egbe NO, et al. Knowledge, Attitudes and Fears of HealthCare Workers towards the Corona Virus Disease (COVID-19) Pandemic in South-South, Nigeria. Health Sci J. 2020; Sp. Iss 1: 002.

13. Zhong B-L, Luo W, Li H-M, Zhang Q-Q, Liu X-G, Li W-T, Li Y. Knowledge, attitudes, and practices towards COVID-19 among Chinese residents during the rapid rise period of the COVID-19 outbreak: a quick online cross-sectional survey. Intl J Bio Sci. 2020;16(10):1745-52. doi:10.7150/ijbs. 45221.

14. Erfani A, Shahriarirad R, Ranjbar K, Mirahmadizadeh A, Moghadami M, Knowledge. Attitude and Practice toward the Novel Coronavirus (COVID-19) Outbreak: A Population-Based Survey in Iran. [Preprint]. Bull World Health Organ. 2020; E-pub: doi:http://dx.doi.org/10.2471/BLT.20.256651.

15. Rahman A, Sathi NJ. Knowledge, Attitude, and Preventive Practices toward COVID-19 among Bangladeshi Internet Users. Electron J Gen Med. 2020;17(5):em245. https://doi.org/10.29333/ejgm/8223.

16. Olum R, Chekwech G, Wekha G, Nassozi DR, Bongomin F. Coronavirus Disease-2019: Knowledge, Attitude, and Practices of Health Care Workers at Makerere University Teaching Hospitals, Uganda. Front Public Health. 2020;8:181. doi:10.3389/fpubh.2020.00181.

17. Alfahan A, Alhabib S, Abdulmajeed I, Rahman S, Bamuhair S. In the era of corona virus: health care professionals' knowledge, attitudes, and practice of hand hygiene in Saudi primary care centers: a crosssectional study. J Commun Hospital Int Med Perspect. 2016;6:32151. doi:10.3402/jchimp.v6.32151.

18. Srichan P, Apidechkul T, Tamornpark R, Yeemard F, Khunthason S, Kitchanapaiboon S, et al. Knowledge, Attitude and Preparedness to Respond to the 2019 Novel Coronavirus (COVID-19) Among the Bordered Population of Northern Thailand in the Early Period of the Outbreak: A Cross-Sectional Study. Available from: SSRN 3546046. 2020.

19. $10.21203 /$ rs.3.rs-23501/v1

Ayinde O, Aduroja P, Gbolahan AA, Cross-Sectional. Study on Oyo State Health Care Workers Knowledge, Attitude and Practice Regarding Corona Virus Disease 2019(COVID-19). Available from: DOI: $10.21203 /$ rs.3.rs-23501/v1. 